\title{
Mathematics Self-efficacy and Mistake-handling Learning as Predictors of Mathematics Anxiety
}

\author{
Zeki Aksu ${ }^{1}$, Merve Ozkaya ${ }^{2}$, Solmaz Damla Gedik ${ }^{3}$, Alper Cihan Konyalıoglu ${ }^{2}$ \\ ${ }^{1}$ School of Education, Artvin Coruh University, Artvin, Turkey \\ ${ }^{2}$ School of Education, Ataturk University, Erzurum, Turkey \\ ${ }^{3}$ School of Education, Nevsehir University, Nevsehir, Turkey \\ Correspondence: Zeki Aksu, School of Education, Artvin Coruh University, Artvin, 08000 Turkey.
}

Received: April 9, 2016 Accepted: April 29, $2016 \quad$ Online Published: May 10, 2016

doi:10.11114/jets.v4i8.1533 URL: http://dx.doi.org/10.11114/jets.v4i8.1533

\begin{abstract}
This study aims to analyze the relationship between secondary school seventh grade students' perception of mathematical self-efficacy, mistake-handling learning awareness, and mathematical anxiety; and to define the power of mistake-handling learning and self-efficacy in predicting mathematical anxiety. In this study, relational model was used and the research group consisted of 323 seventh grade students whose ages range from 12 to 14 . According to the findings of the study, when the relationship between mathematical anxiety, self-efficacy, and mistake-handling learning is analyzed, it is observed that there are significant relationships between mathematical anxieties, self-efficacy, and mistake-handling learning. Furthermore, mathematical self-efficacy and mistake-handling learning explain $51 \%$ of the total variance of the mathematical anxiety.
\end{abstract}

Keywords: mathematical anxiety, mistake-handling learning, scale, self-efficacy

\section{Introduction}

It is reported that in academic life, as a result of some educational, physical, and social experiences, various psychological symptoms are observed among students (Reiss, 1991). Frequently encountered in schools, anxiety-related psychological experiences are observed in different levels and conditions. Anxiety is defined in various ways by many researchers who adopt different theories in the related field writings. One of these definitions is condition of excitation, which reveals with bodily, emotional, or mental changes that emerge when an individual encounters a stimulant (Delice, Ertekin, Aydın, \& Dilmac, 2009). Mathematical anxiety, on the other hand, is defined as to feel anxiety and tension in using numbers and solving math problems in everyday and academic life (Sahin, 2000). Some researchers indicate that mathematical anxiety is a notion that emerges as a result of the interaction between diverse factors. Only some of those factors are ranged as: factors related to the mathematical area's own structure, educational factors, factors related to families' attitudes, personal values, expectations from mathematics, causes related to students, teachers, and teaching, environmental factors, mental factors, and individual factors (Sapma, 2013). According to Lazarus, mathematical anxiety is a notion that emerges as a result of the interaction between the factors such as the mathematical area's own structure, educational factors, families' attitudes, and expectations from mathematics (Yenihayat, 2007).

Indeed, anxiety does not only emerge because of the inefficacy that is felt in handling potential treats behaviorally. Individual's inefficacy perception that he/she cannot control the thinking process and emotional arousal degree is effective in the occurrence of anxiety (Bandura, 1988). Therefore, besides the fear that creates the basis for anxiety, individual's inefficacy perception while controlling his/her own cognition is also effective in the occurrence of anxiety (Richards, Richardson, \& Pier, 2002). Thus, it can be stated that in the occurrence of anxiety and indirectly in the occurrence of anxiety sensitivity, self-efficacy plays a determinant role.

Self-efficacy is an important notion that is discussed in Albert Bandura's Social Learning Theory, and it forms basis for various researches. Self-efficacy is a notion that is related to the individual's belief about how to do something that should be done and in which way he/she should organize that work (Bandura \& Schunk, 1981: 587). According to Bandura, self-efficacy is individual's self-belief, judgment and predictions about the success he/she will achieve in doing something (Ekici, 2012). 
According to Social Learning Theory, an individual's perception of self-efficacy is nourished by four sources. These are:

a) Individual's own personal experiences or a person's knowledge of experiences that is gained through the works done to become skillful at a specific activity

b) Other people's experiences; for example, sharing other people's experiences through taking them as role models

c) Verbal persuasion; suggestions taken by an individual about coping with a situation

d) Emotional condition; an individual's control of fear, anxiety, and stress level in evaluating his/her self-efficacy (Askar \& Umay, 2001).

It is thought that individuals' awareness about their own emotions and opinions related to cognitive process and conditions, and their ability to re-organize enable them to analytically analyze their self-efficacy in the process of transforming some behaviors into performances (Cikrikci, 2012). An important factor that determines the quality of the research about self-efficacy is the type of self-efficacy, which will be used in the research (Erzen, 2013). Teacher self-efficacy (Skaalvik \& Skaalvik, 2010), emotional self-efficacy (Galla \& Wood, 2012), computer self-efficacy (Paraskeva, Bouta, \& Papagianni, 2008), and mathematical self-efficacy (Lee, 2009) are only some of these types of self-efficacy. In this study, mathematical self-efficacy type is taken into account.

A mistake made by a student during a lesson becomes an object of mockery among other students. In addition, the student who makes mistake is ashamed of this mistake, feels embarrassed and he/she is offended by the fact that his/her mistake is known by everybody. The student is afraid of making mistake and then he/she has irrational negative feelings as a result of this fear (Akpınar \& Akdogan, 2010). However, making a mistake in a math class is inevitable. Most of the teachers know this fact, and they are using these mistakes to present frequently used misconceptions. Yet it is not that easy to explain this situation in the class. Because of the interactive structure of the class, teachers prefer to avoid making evaluations of the students' mistakes (Ingram, Baldry \& Pitt, 2013).

Recent studies show that this situation does not prevent the importance of learning from mistakes in mathematics. While Borasi (1996) presented a teaching approach in his case study made by using mistakes, Heinze and Reiss (2007) carried out an experimental study. Different from the control group, in the experimental group, mistake-handling approaches are used. In the end of the study, significant differences among students' success are observed. Rach, Ufer, and Heinze (2013) brought a different perspective in the experimental studies that are carried out by mistake-handling activities. All teachers who take part in this experimental group were trained by the researchers. Some of the teachers in this experimental group received training on how to carry out mistake-handling activities in the class, and how to use these faults in the learning process. Beside these trainings, some of them, on the other hand, are informed about the materials related to mistake-handling activities. Whether this application process creates a difference on the students' attitudes towards the mistakes or not is tested by adapt the survey developed by Spychiger, Mahler, Hascher and Oser (1998), into mathematics and conducted it as pre-test and post-test. The survey consists of four factors that are determined by Heinze, Ufer, Rach, and Reiss (2011). These factors are individual use of faults in learning process, teacher behaviour's affective sides in case of fault, teacher behaviour's cognitive sides in case of fault, and the fear of making mistake in math classes (Rach, Ufer \& Heinze, 2013). According to the findings of this study, there is no difference between the experimental and the control groups in terms of individual use of faults, and teacher behaviour's cognitive sides in case of fault. However, there is a significant difference in terms of teacher behaviour's affective sides in case of fault. It is determined that students' fear of making mistake in math class reduces.

No matter how successful the students are in math classes, making a mistake is an expected situation. The important thing is to turn these mistakes into advantages in the learning process. Abovementioned studies show that teachers' use of faults in the learning process brings both affective and cognitive contributions to the students. Studies about learning from faults in mathematics are not sufficient (Heinze, 2005). A survey that can be used to learn from faults in mathematics will enable the experimental studies that are to be held.

This study was carried out with the purpose of analyzing the relationship between seventh grade students' perception of self-efficacy, mistake-handling learning awareness, and mathematical anxieties; and defining the power of mistake-handling learning and self-efficacy in predicting mathematical anxieties.

\section{Methodology}

\subsection{Pattern of the Study}

This study, which aims to define the predictor power of mathematical self-efficacy and mistake-handling, learning variables on mathematical anxiety in secondary school $7^{\text {th }}$ grade students, was developed by relational model. The relational research enables to comprehend and explain the complexity of human behaviors through current phenomenon. On this way, the relationships between behavior patterns and the variables that define the behaviors (Cohen, Manion \& 
Morrison, 2011). Relational research which allow to analyze the relationship between two or more variables, enable us to perform three important practices as follows: (1) to evaluate the relationship between variables, (2) to assess the consistency between variables and (3) to predict (Ary, Jacobs, Sorensen \& Razavieh, 2010). Fraenkel, Wallen and Hyun (2012) state that relational research serves for two important purposes: (1) to explain the human behaviors that are considered to be important and (2) to predict possible results of human behaviors. In this study which has the nature of relational research, it was aimed to determine the power of certain independent variables (mathematical self-efficacy and mistake-handling learning) in predicting dependent variable (mathematical anxiety).

\subsection{Research Group}

Planned as appropriate to the relational model, this study's research group consists of 323 students; 166 (51.4\%) girls and $157(48.6 \%)$ boys. Ages of participants range from 12 to 14 , and these students are receiving education in the $7^{\text {th }}$ grade.

\subsection{Data Collection Tools}

In the process of data collection, Self-efficacy Scale, Mistake-handling Learning Scale, and Mathematical Anxiety Scale are used.

\subsubsection{Self-efficacy Scale (SES)}

Self-Efficacy Scale was developed by Tasdemir (2003) during his research conducted for high school students. The researcher bases the theoretical substructure of his scale on Bandura (1988)'s theoretical substructure related with self-efficacy (Tasdemir, 2003).

The scale consists of four items. The scale was developed as a seven-point Likert type scale to measure increasing academic self-efficacy. Participants express their beliefs related with their academic self-efficacy by marking the item 7 (totally agree) they think it defines them most, item 1 (totally disagree) defining them least and item 4 (neutral) when they have no opinion. The fourth item that is one of the four items in the scale is a reverse item. The increasing scores in other items reveal the increasing academic self-efficacy belief. The Cronbach Alpha reliability coefficient of the scale was found .71 (Tasdemir, 2003). The internal consistency coefficient of self-efficacy scale within the scope this study was found .72. As a result of the confirmatory factor analysis, it was determined that the single factorial model showed coherence at a good level $\left(\mathrm{x}^{2}(1)=.16, \mathrm{x} 2 / \mathrm{Sd}=.16, \mathrm{p}=.69\right.$, RMSEA=.00, CFI=1.00, IFI=1.00, NNFI=1.00, GFI=1.00, $\mathrm{AGFI}=1.00, \mathrm{SRMR}=.00$ ).

\subsubsection{Mistake-handling Questionnaire}

The Turkish language adaptation of the Mistake-Handling Questionnaire developed by Heinze, Ufer, Rach, and Reiss (2011) in Germany was conducted by Aksu, Gedik, Ozkaya and Konyalıglu (2016). The scale including 9 items is in four-point Likert form in accordance with its original form. The Cronbach Alpha reliability coefficient of the scale was found .73 (Aksu et. al., 2016). The internal consistency coefficient of self-efficacy scale within the scope this study was found .73. As a result of the confirmatory factor analysis, it was determined that the single factorial model showed coherence at a good level $\left(\chi^{2}{ }_{(26)}=66.93, \mathrm{x}^{2} / \mathrm{Sd}=2.57, \mathrm{p}=.00, \mathrm{RMSEA}=.07, \mathrm{CFI}=.90, \mathrm{IFI}=.90, \mathrm{NNFI}=.85\right.$, GFI $=.96$, AGFI=.92, SRMR=.05).

\subsubsection{Mathematical Anxiety Scale}

The scale developed by Ikegulu (1988) for secondary school students was adapted to Turkish language by Ozdemir and Guur (2011). The scale tool including 13 positive and 7 negative items is a Likert type scale tool having five-step evaluation. The Cronbach Alpha reliability coefficients of the MAS's sub-dimensions were found .85 for positive attitudes and .91 for negative attitudes (Ozdemir \& Gur, 2011). The Cronbach Alpha reliability coefficients of the MAS's sub-dimensions within the scope of this study were found .85 for positive attitudes and .80 for negative attitudes. As a result of the confirmatory factor analysis, it was determined that the single factorial model showed coherence at a good level $\left(x_{(168)}^{2}=362.26, \mathrm{x}^{2} / \mathrm{Sd}=2.15, \mathrm{p}=.00, \mathrm{RMSEA}=.06, \mathrm{CFI}=.91, \mathrm{IFI}=.91, \mathrm{NNFI}=.84, \mathrm{GFI}=.90, \mathrm{AGFI}=.87\right.$, $\mathrm{SRMR}=.05)$.

\subsection{Process}

The analysis of data collected from the study carried out in order to determine the effect of mathematical self-efficacy and mistake-handling learning of the secondary $7^{\text {th }}$ class students on mathematical anxiety was conducted in two steps. First, the relation type among mathematical anxiety, mathematical self-efficacy and mistake-handling learning was determined through Pearson Product-Moment Correlation Technique. Second, it was observed via Multiple Linear Regression analysis that to what extend the mathematical self-efficacy and mistake-handling learning can predict mathematical anxiety. In this study, the mathematical self-efficacy and mistake-handling learning were evaluated as independent variables and the mathematical anxiety was evaluated as a dependent variable. SPSS 17.0 package was benefited in the conduction of the first and second processes of the research. 


\section{Results}

In this section of the research, the resolutions of the statistical analyses conducted in line with the hypotheses of the research are given place.

3.1 The Relations between Mathematical Self-efficacy, Mistake-handing Learning, and Mathematical Anxiety

Table 1 . The relations between mathematical self-efficacy, mistake-handling learning, and mathematical anxiety

\begin{tabular}{llll}
\hline & 1 & 2 & 3 \\
\hline SE & 1 & & \\
MHL & $.47^{* * *}$ & 1 & 1 \\
MA & $.66^{* *}$ & $.53^{* *}$ & 68.60 \\
\hline Mean & 20.73 & 27.73 & 15.56 \\
Std. Deviation & 5.66 & 5.32 & \\
\hline
\end{tabular}

p $<$.001; SE: Self-Efficacy, MHL: Mistake-Handing Learning, MA: Mathematical anxiety

According to the table above, when the relation between the dependent (mathematics) and independent variables (self-efficacy and mistake-handling learning) of the research is examined, it is observed that there are significant relations between mathematical anxiety and self-efficacy $(\mathrm{r}=.66, \mathrm{p}<.001)$ and mistake-handling learning $(\mathrm{r}=.53, \mathrm{p}<.001)$.

\subsection{Mathematical Self-efficacy and Mistake-handling Learning as Precursor of Mathematical Anxiety}

In order to determine the predictability of mathematical anxiety by self-efficacy and mistake-handling learning, it was decided to apply multiple regression analysis. Before starting regression analysis, some preconditions need to be met. First of all, bilateral relations between variables were examined and it was cared to omit multiple co-linearity. For this purpose, auto correlation status was examined through Durbin-Watson value and it was concluded that the acquired values (1.97) were in normal limits (Field, 2013). In the second stage, the tolerance value $\left(1-\mathrm{R}^{2}\right)$, which is the variance rate that could not be explained by independent variables, and the variance inflation factor (VIF) were examined. As the tolerance value $(1-\mathrm{R} 2=.77)$ was higher than .20 and variance inflation factor $(\mathrm{VIF}=1.28)$ was lower than 10 , it was concluded that there was no multiple correlation problem (Field, 2013).

Table 2. Multiple Linear Regression Model Abstract

\begin{tabular}{llllllllll}
\hline Model & $\mathrm{R}$ & $\mathrm{R}^{2}$ & $\mathrm{TSH}$ & \multicolumn{2}{l}{ Change Statistics } & \multicolumn{2}{c}{ Durbin-Watson } \\
\cline { 4 - 9 } Model 1 & .71 & .51 & 10.93 & $\Delta \mathrm{R}^{2}$ & $\mathrm{~F}$ & $\mathrm{Sd} 1$ & $\mathrm{Sd} 2$ & $\mathrm{p}$ & \\
\cline { 5 - 9 } & & & & .50 & 166.44 & 2 & 320 & .000 & 1.97 \\
\hline
\end{tabular}

In line with the multiple linear regression analysis findings, mathematical self-efficacy and mistake-handling learning explain the $51 \%$ of the total variance of mathematical anxiety $\left(\mathrm{F}_{(2,32)}=166.44, \mathrm{p}<.001\right)$. At the same time, the contribution of mathematical self-efficacy $(\beta=.53, \mathrm{t}=12.03, \mathrm{p}<.001)$ and mistake-handling learning $(\beta=.28, \mathrm{t}=6.41, \mathrm{p}<.001)$ to the model was found significant.

Table 3. Regression table

\begin{tabular}{lllllll}
\hline & Variable & B & Std. Error & $\beta$ & $\mathrm{t}$ & $\mathrm{p}$ \\
\hline Model & Stable & 15.05 & 3.33 & & 4.51 & .000 \\
& SE & 1.46 & .12 & .53 & 12.03 & .000 \\
& MHL & .83 & .13 & .28 & 6.41 & .000 \\
\hline
\end{tabular}

\section{Discussion}

This study aims to analyze the relationship between students' perception of mathematical self-efficacy, mistake-handling learning awareness, and mathematical anxiety; and to determine whether the mistake-handling learning and self-efficacy predict mathematical anxiety or not. According to the analyses conducted in this scope, it was found that there are significant and positive relationships between mathematical self-efficacy, mistake-handling learning and mathematical anxiety. The power of mistake-handling learning and self-efficacy can be considered as a predictors of mathematical anxiety. The multiple regression analysis conducted at the end showed that mathematical self-efficacy and mistake-handling learning explains the mathematical anxiety significantly.

The significant relationship between the variables of mathematical self-efficacy and mistake-handling learning and the mathematical anxiety is an expected finding. However, the positive significant relationship found between mathematical anxiety and mathematical self-efficacy is an unexpected result. Some studies found negative significant relationships between self-efficacy and anxiety (Bandura, 1988; Nie, Lau \& Liau, 2011). Due to the fact that self-efficacy is a positive concept (Hsieh \& Schallert, 2008) and increases self-confidence (Mohammadyari, 2012), it has a negative relationship with anxiety. This is because of the fact that, people who believe that they can achieve a work and feel that they have sufficient information about an issue, do not have a reasonable excuse to feel anxiety about the related issue. The presence of negative relationships between examination anxiety and academic self-efficacy (Erzen \& Odaci, 2014); 
mathematical anxiety and mathematical self-efficacy (Cooper \& Robinson, 1991; May, 2009) generally indicates a reverse relationship between anxiety and self-efficacy. However, the positive relationship between mathematical anxiety and mathematical self-efficacy may result from a few possibilities. The first possibility is the fact that the study group from which the data were collected was seventh grade who focus on certain goals and have high level of success. In other words, the students from whom the data were collected are equipped with sufficient mathematical information and they may feel anxiety with the fear of confusing what they know due to the great deal of information. However, this possibility could not be tested as there were no data collected related to the success level of the student group from which the data were collected. Therefore, further studies are required to reveal how this finding could be obtained.

The finding of positive relationship between mistake-handling learning and mathematical anxiety is a very new finding for the literature. There is no study which analyzes this subject in this way in the literature. In this scope, the positive relationship is an unexpected finding. Yet in another perspective, students start to question more when they make mistake (if they are guided in accurate way) not when they make right (Karadag, 2004). The increase in awareness level of an individual towards mistakes enables him/her to realize that there are so many things that s/he does not know and this, with a high degree of probability, will lead to increase in anxiety level. According to Heinze (2005), making mistakes make a person feel ashamed in affective sense and mistakes show or imply the incompetence of a person. However, mistake awareness of students may be used as a positive effect through the applications carried out consciously. Taking lessons from mistakes is an individual teaching method which allows student to make mistakes and learn from these mistakes; enables students to question and give meaning to what s/he learns (Karadag, 2004). In this sense, more studies are needed to analyze the relationship between mistake-handling learning and mathematical anxiety.

The last finding of this study shows that mistake-handling learning and mathematical self-efficacy significantly explain the mathematical anxiety. The fact that the $51 \%$ of the variances were explained refers that positive changes of students only related to the variables of mistake-handling learning and mathematical self-efficacy will lead to a significant change in mathematical anxiety of students as well. However, positive beta values show that the changes to occur will be positive just like in correlation. In other words, the common increase in mistake-handling learning and mathematical self-efficacy will lead to the significant increase in mathematical anxiety. However, this finding shows that further studies are needed to analyze the relationships between mistake-handling learning and mathematical self-efficacy.

As the assessment instruments used in this study showed the sufficiency of the scales of reliability and validity scales, there is no need for doubts related to any possible problem on findings and scales. In this sense, the obtained results show that mathematical self-efficacy and mistake-handling learning should be confirmed with studies to be conducted with different samples on mathematical anxiety. Especially, the results of the Mistake-Handling Learning Scale to be confirmed with studies on different samplings will help to understand the reasons of the determined relationships.

\section{References}

Akpınar, B., \& Akdogan, S. (2010). Negatif bilgi kavramı: hata ve basarısızlıklardan ogrenme. Batı Anadolu Egitim Bilimleri Dergisi, 1(1), 14-22.

Aksu, Z., Gedik, S. D., Ozkaya, M., \& Konyalıglu, A. C. (2016). The adaptation of the mistake-handling scale into turkish. International Periodical for the Languages, Literature and History of Turkish or Turkic. 11(3), 65-76. http://dx.doi.org/10.7827/TurkishStudies.9414

Askar, P., \& Umay, A. (2001). Perceived computer self-efficacy of the students in the elementary mathematics teaching programme. Hacettepe University Journal of Education, 21(1), 1- 8.

Bandura, A. (1988). Self-efficacy conception of anxiety. Anxiety Research, 1, 77-98. http://dx.doi.org/10.1080/10615808808248222

Bandura, A., \& Schunk, D. L. (1981). Cultivating competence, self-efficacy, and intrinsic interest through proximal self-motivation. Journal Of Personality And Social Psychology, 41(3), 586-598. http://dx.doi.org/10.1037/0022-3514.41.3.586

Borasi, R. (1996). Reconceiving mathematics instruction: a focus on errors. Norwood, NJ: Ablex Publishing Corporation.

Cikrikci, O. (2012). The predictive strength of metacognitive awareness and self efficacy beliefs on life satisfaction among gifted students, Unpublished Master Thesis, KTU, Institute of Educational Sciences, Trabzon, Turkey.

Cohen, L., Manion, L., \& Morrison, K. (2011). Research methods in education, 7th edition. New York, NY: Routledge.

Cooper, S. E., \& Robinson, D. A. G. (1991). The relationship of mathematics efficacy beliefs to mathematics anxiety and performance. Measurement and Evaluation in Counseling and Development, 24(1), 4-11.

Delice, A., Ertekin, E., Aydın, E., \& Dilmac, B. (2009). Ogretmen adaylarının matematik kaygısı ile bilgibilimsel 
inancları arasındaki iliskinin incelenmesi. Uluslararası Insan Bilimler Dergisi, 6(1).

Ekici, G. (2012). Academic self-efficacy scale: the study of adaptation to turkish, validity and reliablity Hacettepe University Journal of Education, 43, 174-185.

Erzen, E. (2013). The investigation of correlations among attachment styles, test anxiety and self efficacy of adolescences who prepare to university entrance examination. Unpublished Master Thesis, KTU, Institute of Educational Sciences, Trabzon, Turkey.

Erzen, E., \& Odaci, H. (2014). The effect of the attachment styles and self-efficacy of adolescents preparing for university entrance tests in Turkey on predicting test anxiety. Educational Psychology: An International Journal of Experimental Educational Psychology. 1-14. http://dx.doi.org/10.1080/01443410.2014.923555

Galla, B. M., \& Wood, B. (2012). Emotional self-efficacy moderates anxiety-related impairments in math performance in elementary school-age youth. Personality and Individual Differences, 52, 118-122. http://dx.doi.org/10.1016/j.paid.2011.09.012

Heinze, A. (2005). Mistake-handling activities in german mathematics classroom. In H. L. Chick \& J. L. Vincent (Eds.), Proceedings of the $29^{\text {th }}$ Conference of the International Group for the Psychology of Mathematics Education (Vol. 3, 105-112). Melbourne (Australien): Melbourne University.

Heinze, A., \& Reiss, K. (2007). Mistake-handling activities in the mathematics classroom: effects of an in-service teacher training on students' performance in geometry. In J. H. Woo, H. C. Lew, K. S. Park \& D. Y. Seo (Eds.), Proceedings of the $31^{\text {st }}$ Conference of the International Group for the Psychology of Mathematics Education (Vol. 3, 9-16). Seoul: PME.

Heinze, A., Ufer, S., Rach, S., \& Reiss, K. (2011). The student perspective on dealing with errors in mathematics class. In E. Wuttke, \& J. Seifried (Eds.), Learning from errors (pp. 65-79). Opladen, Germany: Barbara Budrich.

Hsieh, P. H. P., \& Schallert, D. L. (2008). Implications from self-efficacy and attribution theories for an understanding of undergraduates' motivation in a foreign language course. Contemporary Educational Psychology, 33, 513-532. http://dx.doi.org/10.1016/j.cedpsych.2008.01.003

Ingram, J., Baldry, F., \& Pitt, A. (2013). The influence of how teachers interactionally manage mathematical mistakes on the mathematics that students experience. Eighth Congress of the European Society for Research in Mathematics Education, Antalya, Turkey.

Karadag, Z. (2004). Learning from mistakes: An example on coordinate plane and symmetry. 4thInternational Educational Technology Symposium. Sakarya, Turkey.

Lee, J. (2009). Universals And Specifics Of Math Self-Concept, Math Self-Efficacy, And Math Anxiety Across 41 PISA 2003 Participating Countries. Learning And Individual Differences, 19, 355-365. http://dx.doi.org/10.1016/j.lindif.2008.10.009

May, D.K. (2009). Mathematıcs self-efficacy and anxıety questıonnaıre. Unpublished Doctoral Thesis, Graduate Faculty of The University of Georgia, Athens, Georgia.

Mohammadyari, G. (2012). Comparative study of relationship between general perceived self-efficacy and test anxiety with academic achievement of male and female students, Procedia-Social and Behavioral Sciences, 69, $2119-2123$. http://dx.doi.org/10.1016/j.sbspro.2012.12.175

Nie, Y., Lau, S., \& Liau, K. A. (2011). Role of academic self-efficacy in moderating the relation between task importance and test anxiety. Learning and Individual Differences, 21, 736-741. http://dx.doi.org/10.1016/j.lindif.2011.09.005

Ozdemir, E., \& Gur, H. (2011). Matematik Kayg1sı-Endisesi Olceginin (MKEO) Gecerlik ve Guvenirlik Calısmas1. Egitim ve Bilim, 36(161), 39-50.

Paraskeva, F., Bouta, H., \& Papagianni, A. (2008). Individual characteristics and computer self-efficacy in secondary education teachers to integrate technology in educational practice. Computers \& Education, 50, 1084-1091. http://dx.doi.org/10.1016/j.compedu.2006.10.006

Rach, S., Ufer, S., \& Heinze, A. (2013). Learning from errors: effects of teachers training on students' attitudes towards and their individual use of errors. PNA, 8(1), 21-30.

Reiss, S. (1991). Expectancy model of fear, anxiety, and panic. Clinical Psychology Review, 11, 141-153. http://dx.doi.org/10.1016/0272-7358(91)90092-9

Richards, J. C., Richardson, V., \& Pier, C. (2002). The relative contributions of negative cognitions and self-efficacy to 
severity of panic disorder. Behaviour Change, 19(2), 102-111. http://dx.doi.org/10.1375/bech.19.2.102

Sahin, F. Y. (2000). Math Anxiety, Eurasian Journal of Educational Research, 1(2), 75-79.

Sapma, G. (2013). The statistical methods analysis of the relationship between the success of the mathematics and the anxiety of the mathematics. Unpublished Master Thesis, Marmara University, Institute of Social Sciences, İstanbul, Turkey.

Skaalvik, E. M., \& Skaalvik, S. (2010). Teacher self-efficacy and teacher burnout: a study of relations. Teaching And Teacher Education, 26, 1059-1069. http://dx.doi.org/10.1016/j.tate.2009.11.001

Spychiger, M., Oser, F., Mahler, F. \& Hascher, T. (1998). Fehlerkultur aus der sicht von schu-lerinnen und schulern. der fehlerfragebogen s-ufs: entwicklung und erste ergebnisse. schriftenreihe zum projekt «lernen menschen aus fehlern?», Nr. 4. Padagogisches Institut der Universitat Freiburg, $\mathrm{CH}$.

Tasdemir, O. M. (2003). The examination of relationship among problem solving skills and self-essicacy, locus of control, self-esteem, test anxiety, perfectionizm in giffed children. Unpublished Master Thesis, KTU, Institute of Educational Sciences, Trabzon, Turkey.

Yenihayat, S. A. (2007). The evaluation of relation between math anxiety of primary school and teacher's attitude. Unpublished Master Thesis, Yeditepe University, Institute of Educational Sciences, İstanbul, Turkey.

This work is licensed under a Creative Commons Attribution 3.0 License. 